\title{
FORMATION OF AN ORGANIZATIONAL AND ECONOMIC MECHANISM FOR ENCOURAGING INVESTMENT ACTIVITY OF ENTERPRISES
}

\author{
Tetyana Korytko', Olga Bogutska², Samira Piletska
}

\begin{abstract}
Aggravation of crisis processes in the economy impedes trends in technology improvement, which leads to a certain lag behind the current needs of social reproduction and the need to increase the investment activity of enterprises. Encouraging enterprises' investment activity is carried out through a mechanism in which there are legal, economic, and financial relations between the subjects of investment activity on the attraction of investments predominantly in the priority directions and branches. The research purpose is to determine the essence and provide the author's interpretation of concept "organizational and economic mechanism for encouraging investment activities of enterprises" and to develop its structure. The research subject is the development of the structure of the organizational and economic mechanism for promoting investment activity of enterprises and substantiation of its main elements. Methodology. The methodological basis of the research is a combination of theoretical and scientific methods: analysis, synthesis, systematization and comparison, theoretical and logical generalization. In particular, the following methods are used: analysis and synthesis - when studying the investment activity of the enterprise; systematisation and comparison to identify the elements that determine the structure of the organizational and economic mechanism for promoting investment activities of enterprises; scientific abstraction - for the formation of theoretical generalization and conclusions. The paper considers different interpretations of the concept "organizational and economic mechanism for encouraging investment activities of enterprises". According to the authors, the organizational and economic mechanism for encouraging investment activities of enterprises is a multi-level hierarchical system of the main interconnected elements and their typical groups (subjects, objects, principles, methods, and tools), during and under the influence of which economic relations between all elements of the system are harmonized. Results. As a result of the analysis of the structure of the organizational and economic mechanism, the authors came to the conclusion that any mechanism is a complex structure of interconnected and interacting economic elements, processes, and phenomena that ensure achievement of the set goal. The proposed organizational and economic mechanism for promoting investment activity of enterprises allows investors to minimize investment costs, reduce risks when entering into an investment agreement, or more accurately estimate future revenues from project implementation. Further research directions are deepening of the interrelation of specific features of investment processes in Ukraine with its institutional environment, determination of features of economic relations as the structure of institutes that provide an overflow of investment resources from financial to real sectors of the economy. Practical implications. The practical significance is manifested in the possibility of using the proposed organizational and economic mechanism to encourage investment activities of enterprises, which ensures the effectiveness of managerial influences while promoting investment activity to achieve a specific goal in the external and internal environment of the enterprise. Value/originality. The originality is the substantiation of structural elements of the organizational and economic mechanism for promoting investment activity of enterprises that influence and determine the directions of encouragement of investment activities of enterprises, which allows combining the study of active business processes, financial support, and creation of information support.
\end{abstract}

Key words: investment activity, promotion, mechanism, organizational and economic mechanism, investment activities.

JEL Classification: G31, G11, R11, E22, O14

\footnotetext{
Corresponding author:

${ }^{1}$ Institute of Industrial Economics of the National Academy of Sciences of Ukraine, Ukraine.

E-mail: korytko@nas.gov.ua

${ }^{2}$ Institute of Industrial Economics of the National Academy of Sciences of Ukraine, Ukraine.

E-mail: bogutsk.ol@gmail.com

${ }^{3}$ National Aviation University, Ukraine.

E-mail: 0508486185@ukr.net
} 


\section{Introduction}

In order to keep their positions and increase their competitiveness, enterprises need to constantly develop, master new technologies, expand their activities. Currently, one of the main problems of the development of enterprises in Ukraine is an unsatisfactory age structure of fixed assets, their considerable depreciation and obsolescence. The volume of investments aimed at the implementation of the policy of renewal of fixed assets is insufficient; the problem is complicated by the low level of the financial stability of enterprises, which repel potential investors from investing in their activities.

Thus, the acceleration of the rate of decline in capital investments as a result of the impact of the global financial crisis observed in Ukraine, as in all emerging markets since 2009, has been aggravated by the economic downturn as a result of the conflict in the East of Ukraine after 2014, when an increase in the rate of decline capital investment ranged from 7 to $51 \%$, and some recovery, beginning in 2015 , still did not allow reaching the pre-crisis level of 2004-2007, when the increase in the growth rate of capital investment amounted to about $10-15 \%$ annually compared with the same period. The foregoing stipulated the necessity of developing measures to promote the intensification of investment activities of enterprises.

Encouraging enterprises' investment activity is carried out through a mechanism in which there are legal, economic, and financial relations between the subjects of investment activity on the attraction of investments predominantly in the priority directions and branches. Therefore, for making sound managerial decisions in the field of investment activities, it is necessary to form a complex effective organizational and economic mechanism for promoting investment activities.

Such scholars as O. I. Amosha (2005), I. P. Buleev (2006), O. S. Khryniuk \& M. O. Derhaliuk (2017), O. V. Savchenko \& V. P. Soloviov (2013), I. V. Bryl (2015), S. T. Piletska (2016), A. H. Honcharuk (2009) and others devoted their works to issues of the essence of "mechanism" and "organizational and economic mechanism" concepts.

However, despite a large number of publications confirming the relevance of this study, the essence of the concept of "organizational and economic mechanism" is still controversial, which, in turn, creates difficulties in developing effective tools for its implementation.

The purpose of the article is to determine the essence and provide the author's interpretation of concept "organizational and economic mechanism for encouraging investment activities of enterprises" and to develop its structure.

\section{The essence of the concept of "organizational and economic mechanism for encouraging investment activities of enterprises"}

There is a great deal of thought about the nature of these concepts, but so far there is no clear terminological definition. In order to understand the essence of the concept of a mechanism for promoting investment activity, it should be noted what is included in the content of the concept of "mechanism".

The term "mechanism" (from the Greek: mechane - machine) means a device that transmits or converts motion, internal structure, the system of something; a set of states and processes that make up a certain phenomenon (Bucel, 2003; Kalashnik, 2002). Analysis of scientific works gives grounds to distinguish two main approaches to the consideration of the essence of the concept of "organizational and economic mechanism" (Table 1).

Within the first approach, the organizational and economic mechanism is considered as a set of forms, methods, tools, and levers of influence on the activity of objects in order to achieve a certain effect. Among the supporters of this approach are O. S. Khryniuk, M. O. Derhaliuk (2017), A. H. Honcharuk (2009), I. V. Chukina (2014), and others. The definition according to the first approach is quite universal and reflects the elements of actions of the management system on the managed one.

It is necessary to agree with the authors' opinion regarding such an interpretation of this concept, but one important issue remains unanswered about the need for constant monitoring of such a mechanism. The organizational and economic mechanism should use market levers and natural connections between elements of the system, supplemented by organizational instruments of influence.

Within the second approach supported by O. V. Savchenko, V. P. Soloviov (2013), S. S. Savina (2012) and others, the organizational and economic mechanism is considered as a system that defines the order of a certain type of activity that has a complex, organized structure. This approach does not contradict the very essence of the mechanism itself since the need to achieve the goal is stimulated by the development from initial economic phenomena to final ones without additional impulses.

The concept "investment activity" was studied by such domestic scholars as N. Ye. Bryukhovetska, T. Yu. Korytko, I. V. Bryl (2016), N. Ye. Bryukhovetska, L. V. Ivanenko (2017), V. Ye. Budyakov (2008), T. Z. Charhaziya (2014), V. M. Butyrina, T. Z. Charhaziya (2012), O. A. Bohutska, Ia. S. Bryukhovetskyi. Based on the above definitions, one can conclude that, on the one hand, the concept of "investment activity" is defined as a synonym for "investment activities", which covers the style and nature of the actions of actors in the investment market and in the extended investment process, on the other - as its directed 
Table 1

Definition of the concept "organizational and economic mechanism"

\begin{tabular}{|c|c|}
\hline Author & Essence \\
\hline $\begin{array}{l}\text { O. S. Khryniuk, } \\
\text { M. O. Derhaliuk } \\
\quad(2017)\end{array}$ & $\begin{array}{l}\text { a certain system of elements of the organizational and economic nature (objects, subjects, goals, tasks, methods of } \\
\text { interaction, methods, levers, tools, etc.), interconnected and interacting with each other with moving internal and } \\
\text { external connections at the macro, meso, micro levels of the economy, its inter-branch complexes, branches, primary } \\
\text { links, etc., the effectiveness of its implementation depends on the ability to create connections, elements, incentives, } \\
\text { etc., which are absent at a particular moment }\end{array}$ \\
\hline $\begin{array}{l}\text { A. H. Honcharuk } \\
\qquad(2009)\end{array}$ & $\begin{array}{l}\text { a system of methods, operations, levers, organizational structures and their interconnections, which determine the } \\
\text { content of the management process }\end{array}$ \\
\hline $\begin{array}{l}\text { O. P. Khaietska } \\
\text { (2016) }\end{array}$ & $\begin{array}{l}\text { a system of organizational and economic levers, instruments, factors influencing the economic activity of enterprises, } \\
\text { industries, product subcomplexes, aimed at increasing its efficiency }\end{array}$ \\
\hline $\begin{array}{l}\text { O. V. Savchenko, } \\
\text { V.P. Soloviov } \\
\quad(2013)\end{array}$ & $\begin{array}{l}\text { a part of the system of management in a specific period of development of the national economy of any country, } \\
\text { representing a combination of two heterogeneous but interrelated components - the organizational component and } \\
\text { economic component }\end{array}$ \\
\hline $\begin{array}{l}\text { I. V. Chukina } \\
\text { (2014) }\end{array}$ & $\begin{array}{l}\text { a set of organizational and economic levers operating on the organizational and economic parameters of the } \\
\text { management system and promoting the acquisition of competitive advantages, the formation and strengthening of } \\
\text { organizational and economic potential and the efficiency of the enterprise as a whole }\end{array}$ \\
\hline $\begin{array}{l}\text { A. V. Cherep, } \\
\text { D. V. Krylov } \\
\quad(2014)\end{array}$ & $\begin{array}{l}\text { process of planning, organization, regulation, control over the economic, industrial, social development of industrial } \\
\text { enterprises, the level of investment potential, investment activity through the observance of legal, economic, } \\
\text { organizational levers and through the implementation of methods, functions, principles, ways of attracting } \\
\text { investment resources, accumulation of savings, rational use of resources, taking into account the threats of the } \\
\text { investment market in order to minimize risks and develop investment projects }\end{array}$ \\
\hline $\begin{array}{l}\text { H. V. Kozachenko } \\
\text { (2003) }\end{array}$ & $\begin{array}{l}\text { a management tool, which is a set of management elements and methods of their organizational, informational, } \\
\text { motivational, and legal support, through the use of which, taking into account the specific features of the enterprise, } \\
\text { achieving a certain goal is provided }\end{array}$ \\
\hline $\begin{array}{l}\text { S. S. Savina } \\
(2012)\end{array}$ & $\begin{array}{l}\text { a complex system that includes subsystems of forecasting and planning of development, motivation, organization, } \\
\text { information provision }\end{array}$ \\
\hline O. M. Shkilniuk & $\begin{array}{l}\text { a system of organizational, economic, legal, managerial, and regulatory actions, methods, and tools that shape and } \\
\text { influence the order of its implementation for achieving the expected socio-economic and other results }\end{array}$ \\
\hline $\begin{array}{l}\text { A. Sokolova } \\
\text { (2009) }\end{array}$ & $\begin{array}{l}\text { purposeful and managed open system of organizational, economic, legal, managerial, and regulatory actions, } \\
\text { methods, and processes that shape and influence the order of activity in the Ukrainian economy that will contribute } \\
\text { to the achievement of the expected economic, social, environmental, and other results. }\end{array}$ \\
\hline
\end{tabular}

general characteristics, tendencies of investment change, as an indicator of the efficiency of investment resources use or the result of investment decisions. Consequently, investment activity reflects quantitative and qualitative aspects of investment activities.

Thus, the organizational and economic mechanism for encouraging investment activity of enterprises should be understood a multilevel hierarchical system of the basic interconnected elements and their typical groups (subjects, objects, principles, methods, and tools), during and under the influence of which economic relations between all elements of the system are harmonized. Since any mechanism is a complex structure of interconnected and interacting economic elements, processes, and phenomena that ensure the process of achieving the goal, it is necessary to determine its clear structure that will realize functions determined by the mechanism.

\section{The structure of the organizational and economic mechanism for encouraging investment activity of enterprises}

Organizational and economic mechanism changes depending on the field of application; however, there are common elements that determine its composition and structure. Determining the structure of the organizational and economic mechanism, most authors such as I. P. Buleev, I. D. Paderin (2006), O. S. Khryniuk, M. O. Derhaliuk (2017) take into account such components as goals, principles, and tasks of management, methods, levers and instruments, areas and functions of management, organizational, institutional, legal, informational, financial, and other support. In studies by S. S. Savina (2012), A. Sokolova (2009), three systems are combined in the organizational and economic mechanism: a support system, functional system, and target system. The generalization of the main approaches allowed forming the structure of the organizational and economic mechanism for promoting investment activity of the enterprise (Figure 1).

The purpose of the organizational and economic mechanism for encouraging investment activity of enterprises is the economic incentive to intensify investment activities of enterprises through direct and indirect methods and instruments of influence. Theobject of the organizational and economicmechanism for encouraging investment activity of enterprises is the process of ensuring the effective performance of the enterprise on the basis of increasing investment activity. 


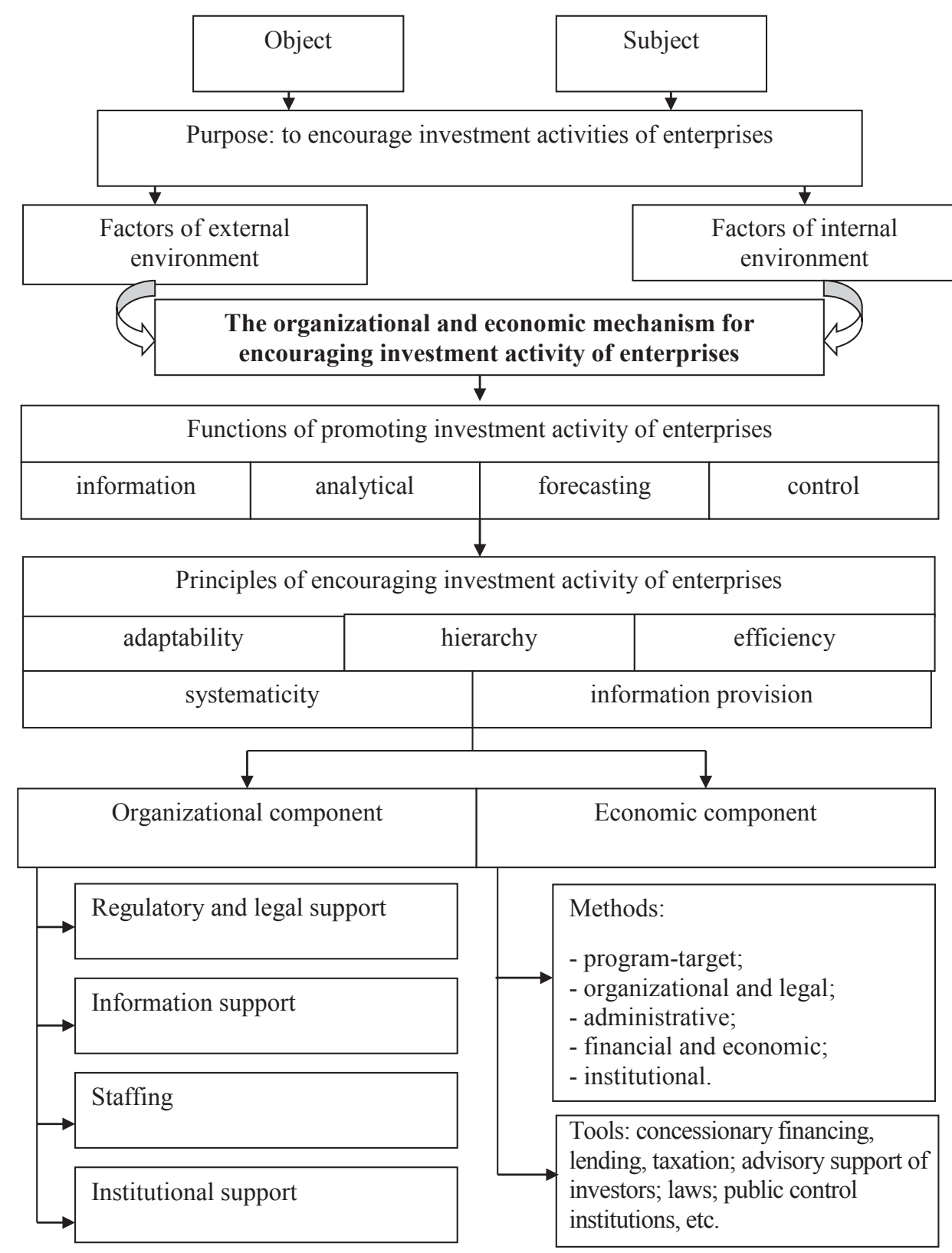

Figure 1. The organizational and economic mechanism for encouraging investment activity of enterprises

The totality of subjects of the organizational and economic mechanism is determined by sources of financing of investment attraction, among which state, private, and mixed are traditionally distinguished. The subjects of the organizational and economic mechanism for promoting investment activity of enterprises are the state, enterprise owners, its management, and investors.

The basis of the organizational and economic mechanism for encouraging investment activity of enterprises is its principles. Based on the analysis of works by V.I. Meyta (2014), Ye. O. Holyshcheva (2012), O. I. Vyshnytska (2011), the authors identified the following principles of an organizational and economic mechanism for promoting investment activity of enterprises:
- the principle of information provision characterizes the formation and use of information base. The result of the analysis of investment activity is the preparation of an analytical conclusion on the current and future financial position of the company and the reasonableness of the planned activities;

- the principle of adaptability is to provide the flexibility of the mechanism created in accordance with the dynamics of the internal and external environment of the enterprise; - the principle of systemacity determines that the mechanism should be considered in a single set of object and subject;

- the principle of hierarchy means that the structure should have several management levels, that is, for the division of decision-making powers; 
- the principle of efficiency, that is, the choice of methods, means of influence, which lead to the achievement of objectives set by the authorities, as well as the coordination of objectives of the subject and object of management.

Besides the principles, a basic component of the organizational and economic mechanism for encouraging investment activity of enterprises is its functions. O. V. Savchenko, V. P. Soloviov (2013), S. S. Savina (2012), O. O. Seleznova (2012), and others give a full list of functions that are key and will help to solve problems related to stimulating enterprise investment activity.

Given the results of the analysis of the mentioned authors on the definition of functions of the organizational and economic mechanism, taking into account the peculiarities of promoting the enterprise investment activity, we distinguish the main functions: information one provides with all necessary information (collection, processing, grouping, and transfer of accounting data by appointment) in order to encourage investment activity of the enterprise; analytical allows revealing the influence of investment activity of the enterprise on its operating performance by conducting an estimation of the investment activity of the enterprise and determination of factors influencing its dynamics; forecasting creates the basis for the formation of current and perspective forecasts and contributes to the effective use of financial and economic tools to encourage the investment activity of the enterprise; control creates preconditions for preventing and overcoming crisis situations by assessing investment activities from the point of view of legality and expediency, observance of resource expenditure rates; the use of operational, tactical, and strategic measures, associated with the occurrence of deviations in the activities of subdivisions, etc.

Ensuring investment activity of enterprises and increasing the efficiency of its promotion processes is ensured by program-target, organizational-legal, administrative, financial-economic, and institutional methods. Each method requires the use of appropriate tools.

Traditionally, all methods and, accordingly, promotion tools that underlie any organizational and economic mechanism are divided into direct and indirect (Voloshin, Shekhlovich, 2014; Tarakanov, 2016). In the mechanism for encouraging investment activity of enterprises, the state plays a leading role through the forms of direct and indirect influence on the investment attraction by enterprises, each of which is realized by means of specific methods and instruments. Direct ones include program-target methods and their corresponding tools, by which investment resources are allocated to the execution of a specific program or project. Indirect methods that promote the creation of favourable conditions for attracting investment and releasing financial resources for investment needs should include financial, economic, and institutional methods and tools. The authors propose to associate administrative and organizational-legal methods based on their implementation tools and application specifics with mixed methods of promoting investment activity of enterprises. As a component of the organizational and economic mechanism for encouraging the investment activity of the enterprise, particular attention is required for:

program-target methods, which include: budget financing of priority investment projects determined by the state; state risk insurance of enterprises investing in priority sectors for the development of high-tech industries; government procurement of products of innovatively active enterprises investing resources in upgrading and modernizing the priority industries (tools - investment out of budget funds, subsidies, subventions, grants, government procurement, etc.);

organizational and legal methods are, first of all, legislative and statutory provision that guarantees the legal protection of investors' interests, ensuring the transparency and efficiency of the judicial system (tools - target investment programs, laws, regulations, and documents, which clearly define the guarantees of investor rights, precedents for settlement of investment disputes, competition laws);

administrative methods include the development of an effective investment development strategy of the country and its individual regions aimed at creating favourable conditions for investment activities and support of investors, the formation of an appropriate investment policy (tools - advisory support of investors, patent and licensing policy, etc.);

financial and economic methods include the formation of differentiated tax and flexible depreciation policies, creation of conditions for attracting non-traditional investment sources (leasing, crowdfunding, forms of venture financing, etc.), financial and credit methods of promoting investment activity of enterprises, simplifying access of enterprises to credit resources (tools - concessionary financing, lending and taxation; simplification of the procedure for attracting investment resources in the financial market; creation of development banks; and also prices, bonuses, rates, subsidies, tariffs, etc.);

institutional methods provide an opportunity for more intensive promotion of investment resources through the simplification of the interaction of formal and informal institutes and institutions - statuses, constraints, sustainable way of thinking, contracts, patterns of behaviour and decision-making, legal norms, rules, regulations, rights of individual social strata and groups, and other systems of ties between 
subjects of investment relations (tools - facilitating the development of institutions of public control over the activity of state authorities in the investment sphere; transformation of the mental stereotypes of the conduct of economic relations).

The regulatory support for the organizational and economic mechanism for promoting investment activity of enterprises is the regulatory framework, determines the position of the subject of investment activity, establishes legal responsibility, and exercises control over the relations between the participants and the state.

The regulatory support in the sphere of investment activity includes the Law of Ukraine "On Investment Activity" that is aimed at ensuring equal protection of the rights, interests, and property of the subjects of investment activity, regardless of ownership, as well as effective investment of the Ukrainian economy, development of international economic cooperation and integration. The Law of Ukraine "On Protection of Foreign Investments in Ukraine" aims to protect investments, profits, legal rights and interests of foreign investors on the territory of Ukraine. The features of the regime of foreign investment in Ukraine were established by the Law of Ukraine "On the Regime of Foreign Investment". The Law of Ukraine "On Special Regime of Investment and Innovative Activities of Technological Parks" defines the legal and economic bases for the introduction and functioning of the special regime of investment and innovation activities of technological parks and other legislative acts.

The peculiarity of domestic investment legislation is that certain aspects in the investment sphere, in addition to the above-mentioned regulatory acts, are also regulated by the provisions of the Commercial and Tax Codes and other legislative acts aimed at supporting the increase of investment activity of the Ukrainian economy.

Information support of organizational and economic mechanism for promoting investment activity of enterprises is a process of continuous targeted selection of relevant information indicators for internal and external users of the enterprise for analysis, planning of control, and preparation of effective management decisions in all aspects of investment activities. Information support is aimed at providing the necessary information to management personnel, owners of the enterprise, as well as interested users. Formation of information provision of organizational and economic mechanism for encouraging investment activity of enterprises, definition of content and composition of management information are carried out by means of detection and use of dependencies and regularities of behaviour of subjects and objects of investment processes; construction of information models, the basis of which is structural-functional analysis, forecasting, and dynamic situational modelling.

Staffing of organizational and economic mechanism for promoting investment activity of enterprises is the training of staff in accordance with the needs of investment processes in the economy, as well as the continuous staff development in connection with the development and implementation of investment projects in the enterprise.

Institutional support of the organizational and economic mechanism for promoting investment activity of enterprises is a special kind of incentive of economic entities to manifest investment activity, which is formed through the establishment of certain rules (institutions) that allow regulating the economic behaviour of enterprises, as well as a set of certain alternatives, of which indicated actors make their choice.

The subjects of institutional support are state authorities of investment activity management, which perform functions of promotion and regulation with the help of institutional methods and tools, and using the system of ensuring the activities of various institutions affect the object of institutional encouragement - the investment activities of enterprises through the formation of a favourable institutional environment. State regulatory and administrative authorities of different levels define and form priorities, directions, goals, and tasks of investment development of the economy as a whole, its individual spheres and sectors. This is reflected in legislative, regulatory, and program documents (formal institutes).

\section{Conclusions}

Thus, encouragement of investment activity of enterprises is carried out through the organizational and economic mechanism, which is a system of relations arising from the attraction of investments, the main elements of which are the subjects of investment activity, their purpose, a set of methods and tools, staffing, regulatory, informational, and institutional support on the basis of the principles of promoting investment activity in order to achieve a certain goal in the conditions of external and internal environment of the enterprise.

The determined organizational and economic mechanism for stimulating investment activity is based on the application of program-target, organizationallegal, administrative, financial-economic, and institutional methods and corresponding tools in resources allocation, which ensures target allocation of resources and maximum efficiency of investments. It allows investors to minimize investment costs, reduce risks when entering into an investment agreement, or more accurately estimate future revenues from project implementation. 


\section{References:}

Amosha, O. I. (2005). Orhanizatsiyno-ekonomichni mekhanizmy aktivizatsiyi innovatsiynoi diyalnosti [Organizational and Economic Mechanisms for Activating Innovation in Ukraine]. Economy of industry, 5, $15-21$.

Buleev, I. P., Paderin, I. D. (2006). Sinirgiticheskijj effect povyshenija ekonomicheskojj effektivnosti v Ukraine [Synergetic effect of increasing the economic efficiency of an industrial enterprise]. Economy. Finances. Right, 1, 15-21.

Bryl, I. V., Vasylenko, T. D. (2015). Vyznachennya etapiv mekhanizmu upravlinnya nematerialnymy aktyvamy padpryemstva [Determination of stages of the management mechanism of intangible assets of the enterprise]. Strategy and mechanisms of regulation of industrial development.

Bucel, V. T. (2003). Velykyi tlumachnyi slovnyk suchasnoyi ukrayinskoyi movy [Great tlumachny dictionary of Ukrainian]. K.: Irpin: WTF "Perun".

Bryukhovetska, N. Ye., Korytko, T. Yu., Bryl, I. V. (2016). Otsinyuvannya investytsiynoyi akryvnosti pidpryemstva za kriteriem dodanoyi vartosti [Estimation of investment activity of the enterprise on the criterion of added value]. Strategy and mechanisms of regulation of industrial development.

Bryukhovetska, N. Ye., Ivanenko, L. V. (2017). Nauchnye podkhody k opredeleniju ehkonomicheskojj sushhnosti investicionnojj aktivnosti predprijatijj Ukrainy I ee ocenka [Scientific approaches to the definition of the economic essence of investment activity of enterprises of Ukraine and its evaluation]. Problems of the economy, 2, 184-192.

Budyakov, V. Ye. (2008). Metody pidvyshchennya investytsiynoyi aktyvnosti rehionu [Methods of increasing investment activity in the region] (PhD Thesis), Donetsk: Institute of economic and legal research.

Butyrina, V. M., Charhaziya, T. Z. (2012). Investicionf aktivnost ta proaktyvnist v ekonomitsi mista [The essence and features of investment activity in the economy of a large industrial city]. Scientists note the Taurian National University, 3, 46-54.

Bohutska, O. A., Bryukhovetskyi, Ia. S. (2017). Ocenka urovnja investicionno-innovacionnojj aktivnosti vo vzaimisvjazi s politilojj intelektyalizacii I motivacii tryda personala promyshlennukh predprijatijj [Evaluation of the level of investment and innovation activity in connection with the policy of intellectualization and motivation of labor of industrial personnel]. Visnyk ekonomicheskojj nauki Ukrainu, 1, 19-25.

Chukina, I. V. (2014). Orhanizatsiyno-ekonomichni mekhanizm u systeni upravlinnya vyrobnycho-hospodarskoyi diyalnosti ahrarnykh pidpryemstv [Organizational and economic mechanism in the system of management of production and economic activity of agrarian enterprises]. Economic analysis, 3, 230-236.

Cherep, A. V., Krylov, D. V. (2014). Orhanizatsiyno-ekonomichni mekhanizm investytsiynykh proektiv [Organizational and economic mechanism of investment projects of industrial enterprises: the essence, approaches to the definition]. Economic Herald of the University, 30(1), 102-108.

Shkilniuk, O. M. Orhanizatsiyno-ekonomichni mekhanizm reguluvannya innovatsiynoyi diyalnosti [Organizational and economic mechanism of regulation of innovation activity $]$ (PhD Thesis), Kyiv: Research Institute of Economics. Charhaziya, T. Z. (2014). Sutnist ta osoblyvosti investicionnojj aktivnosti v ekonomitsi promyslovoho mista [The essence and features of investment activity in the economy of a large industrial city]. Investment Economics, $5,157-162$.

Honcharuk, A.H. (2009). Formirovanie obshego mekhanizma upravlenija ehffektivnostju predprijatiha [Formation of the overall mechanism of enterprise performance management]. Economy of industry, 2, 164-175.

Holyshcheva, Ye. O. (2012). Pryntsypy formuvannya orhanizatsiyno-ekonomichni mekhanizmu upravlinnya spozhyvchim kapitalom promyslovoho pidpryyemstva [Principles of formation of organizational and economic mechanism of management of consumer capital of an industrial enterprise]. Effective economy (electronic journal), no. 7. Retrieved from: http://www.economy.nayka.com.ua/?op=1\&z=2635 (accessed 10 May 2018)

Khryniuk, O. S., Derhaliuk, M. O. (2017). Henezys naukovoyi dumky shchodo ponyattya «orhanizatsiynoekonomichnyi mekhanizm» [Genesis of scientific thought regarding the concept of "organizational and economic mechanism"]. Economic Bulletin of NTUU "KPI", 14, 82-97.

Kalashnik, V. S. (2002). Tlumachnyi slovnyk ukrayinskoyi movy [Interpretative dictionary of the Ukrainian language]. Kharkiv: Flag.

Khaietska, O. P. (2016). Formuvannya ta efektyvne funktsionuvannya orhanizatsiyno-ekonomichnoho mekhanizmu tsukroburyakovoho vyrobnytstva [Formulation and effective functioning of the organizationeconomical mechanism of the Tsukroburyak vibrobitvita]. Agrosvit, 17, 37-43.

Kozachenko, H. V. (2003). Orhanizatsiyno-ekonomichni mekhanizm yak instrument upravlinnya pidpryemstvom [Organizational and economic mechanism as an enterprise management tool]. Economy. Management. Enterprise, $11,107-111$.

Meyta, V. I. (2014). Formuvannya orhanizatsiyno-ekonomichni mekhanizmu upravlinnya ekonomicjnoyu bezpekoyu pidpryemnytskoyi diyalnosti [Formation of organizational and economic mechanism for managing economic security of entrepreneurial activity]. Scientific notes of the National University "Ostroh Academy", 27, 15-19. Piletska, S. T. (2016). Orhanizatsiyno-ekonomichni mekhanizm realizatsiyi stratehiyi zabezpechennya innovatsiynoyi akryvnoati aviapidpryemstv [Organizational and economic mechanism for implementing the strategy for providing innovative activity of airlines]. Economic Herald of the National Mining University, 1(53), 102-109. 
Savchenko, O. V., Soloviov, V. P. (2013). Sutnist ta skladovi orhanizatsiyno-ekonomichni mekhanizmu stymulyuvannya innovatsiynoi diyalnosti pidpryemstva [The essence and components of the organizational and economic mechanism for stimulating innovation activity in the enterprise]. Effective economy (electronic journal), no. 12. Retrieved from: http://www.economy.nayka.com.ua/?op=1\&z=2635 (accessed 10 May 2018)

Savina, S. S. (2012). Orhanizatsiyno-ekonomichni mekhanizm upravlinnya pidpryemstvom molochnoyi promyslovosti [Organizational and economic mechanism of the management of the dairy industry]. Collection of scientific works of VNAU, 3, 162-166.

Sokolova, A. (2009). Orhanizatsiyno-ekonomichni mekhanizm formuvannya kooperatyviv v Ukrayini [Organizational and economic mechanism of functioning of cooperatives in Ukraine]. Bulletin of the Kiev National Trade and Economic University, 2, 88-96.

Seleznova, O. O. (2012). Orhanizatsiyno-ekonomichnyi mekhanizm upravlinnya rynkovoyu diyalnistyu rozdribnykh torhovelbykh pidpryyemstv: monohrafiia [Organizational and economic mechanism of managing the market activity of retail trade enterprises: monohrafiia]. Odessa: KP OMD.

Tarakanov, V. V. (2016). Mekhanizm finansovoho stymulirovanija investicionnojj dejatelnosti [Mechanism of financial incentives for investment activities]. Bulletin of Volgograd State University, 1(34), 98-6105.

Vyshnytska, O. I. (2011). Formuvannya orhanizatsiyno-ekonomichnoho mekhanizmu upravlinnya ekolohichnooriyentovanymy investytsiynymy proektamy [Formation of organizational and economic mechanism of management of environmentally-oriented investment projects]. Bulletin of the Sumy State University, 3, 58-63.

Voloshin, V. I., Shekhlovich, A. M. (2014). Instytutsiyni mekhanizmy ta instrumenty upravlinnya innovatsiynoyi bezpeky Ukrayiny [Institutional Mechanisms and Tools for Managing Innovation Security in Ukraine]. Actual problems of international relations, 122, 109-116. 